Purdue University

Purdue e-Pubs

LARS Symposia

Laboratory for Applications of Remote Sensing

$1-1-1981$

\title{
On the Slope-Aspect Correction of Multispectral Scanner Data
}

\author{
P. M. Teillet \\ B. Guindon \\ D. G. Goodenough
}

Follow this and additional works at: http://docs.lib.purdue.edu/lars_symp

Teillet, P. M.; Guindon, B.; and Goodenough, D. G., "On the Slope-Aspect Correction of Multispectral Scanner Data" (1981). LARS Symposia. Paper 444.

http://docs.lib.purdue.edu/lars_symp/444

This document has been made available through Purdue e-Pubs, a service of the Purdue University Libraries. Please contact epubs@purdue.edu for additional information. 
Reprinted from

\title{
Seventh International Symposium
}

\author{
Machine Processing of
}

Remotely Sensed Data

with special emphasis on

\section{Range, Forest and Wetlands Assessment}

\author{
June 23 - 26, 1981 \\ Proceedings
}

\author{
Purdue University \\ The Laboratory for Applications of Remote Sensing \\ West Lafayette, Indiana 47907 USA
}

\section{Copyright (C) 1981}

by Purdue Research Foundation, West Lafayette, Indiana 47907. All Rights Reserved.

This paper is provided for personal educational use only, under permission from Purdue Research Foundation.

Purdue Research Foundation 
ON THE SLOPE-ASPECT CORRECTION OF MULTISPECTRAL SCANNER DATA

\author{
P.M. TEILleT, B, GUINDON, D, G, GOODENOUGH
}

Canada Centre for Remote Sensing

Ottawa Canada

ABSTRACT IN LIEU OF MANUSCRIPT slope, aspect, incidence angle, reflection angle) and MSS radiance values are investigated for the different forest types under consideration at each site.

The analysis encompasses multitemporal Landsat MSS data at a resolution of 50 metres and II channel airborne MSS at resolutions of 20 and 50 metres. Slopeaspect correction algorithms for both of these types of data are implemented in software on the image analysis system at the Canada Centre for Remote Sensing. Geometric rectification is also a prerequisite in order to relate image geometry to the map coordinates on which the digital terrain data are based. A special technique involving flight line modelling is used to accomplish this in the case of aircraft data since prior knowledge of the terrain elevation is needed for each image pixel in order to establish an undistorted transformation.

Feature selection based on divergence criteria indicates that terrain parameters compare favourably with the MSS data in terms of ability to distinguish between forest classes. However, maximum likelihood classification results for MSS data, corrected for slope-aspect effects using a variety of functions, show little or no significant improvement over results obtained using uncorrected data. This outcome is discussed with a view to achieving a better understanding of both the physical principles and the image processing methodologies involved. 